\title{
Pneumonitis as A Consequence of (Peg)Interferon-Ribavirin Combination Therapy for Hepatitis C: a Review of the Literature
}

\author{
Serena Slavenburg $\cdot$ Yvonne F. Heijdra • \\ Joost P. H. Drenth
}

Received: 3 December 2008/ Accepted: 17 March 2009/Published online: 28 April 2009

(c) The Author(s) 2009. This article is published with open access at Springerlink.com

\begin{abstract}
Combination of peginterferon and ribavirin is the current therapy for chronic hepatitis $\mathrm{C}$ infection (HCV). Interstitial pneumonitis is a rare side-effect of $\mathrm{HCV}$ therapy and is an important cause of dose reduction or discontinuation, impairing success of antiviral therapy. We performed a review of the literature in order to present diagnostic modalities and possible treatments for pneumonitis and to offer guidelines. We searched for cases where pneumonitis as a side-effect of HCV treatment was documented. First we performed a literature search via PubMed and Web of Science interface and second we searched three drug toxicity databases. We systematically analyzed all case reports with respect to clinical manifestations, type of treatment, and outcome. A literature search revealed 19 articles, containing 25 case descriptions, while we traced 33 cases from the drug toxicity databases. Pneumonitis presented with any of the combination of fever, dyspnea, and cough and can arise with any type of (conventional or pegylated) interferon. Mortality secondary to pneumonitis was seen in $7 \%$ of cases, exclusively with peginterferon $\alpha$-2b. In most cases therapy was discontinued and steroids were started. Interferon-induced pneumonitis during HCV treatment is a severe complication and should be recognized in order to prevent further pulmonary damage and/or death.
\end{abstract}

S. Slavenburg $(\bowtie) \cdot$ J. P. H. Drenth

Department of Gastroenterology and Hepatology, Radboud

University Nijmegen Medical Center, P.O. Box 9101, 6500 HB

Nijmegen, The Netherlands

e-mail: S.Slavenburg@MDL.umcn.nl

Y. F. Heijdra

Department of Pulmonary Diseases, Radboud University

Nijmegen Medical Center, Nijmegen, The Netherlands
Keywords Hepatitis C · (Peg)Interferon - Ribavirin · Toxicity $\cdot$ Pneumonitis

\section{Introduction}

Hepatitis C (HCV) persists in up to $85 \%$ of patients and may result in liver cirrhosis and hepatocellular carcinoma [1]. The combination of peginterferon and ribavirin is the mainstay of treatment. Eradication of the virus can be achieved in up to $90 \%$ of chronic HCV patients, depending on a number of host- and virus-related factors $[1,2]$. Successful treatment results in resolution of hepatic necroinflammation and regression of fibrosis.

Though potentially successful, peginterferon and ribavirin are known to cause various side-effects in $\mathrm{HCV}$ patients. Most individuals suffer from some side-effects such as flu-like symptoms, myalgia, fatigue, gastrointestinal disturbances, psychiatric disorders, and hematological abnormalities such as anemia and leukopenia [3-5].

These adverse effects are relatively common and can be managed with supportive care. There are also less wellknown side-effects of antiviral treatment that may hamper successful eradication of the virus. Knowledge of the extensive gamut of side-effects of combination therapy is critical for the adequate management of side-effects.

Pulmonary toxicity in patients undergoing HCV combination treatment is rare, and may include interstitial pneumonitis, sarcoidosis, pleuritis, bronchiolitis obliterans organizing pneumonia (BOOP), and exacerbation of asthma $[6,7]$. Pneumonitis occurs only rarely as a side-effect of HCV combination therapy and can arise at any stage of the treatment. Most commonly it presents with cough, which is difficult to differentiate from the ubiquitous cough that may occurs as a common side-effect of combination treatment. 
Interferon is the agent that is thought to be associated with pneumonitis in these patients. This paper aims to review the salient issues of pneumonitis in the setting of HCV combination treatment and aims to offer guidelines for diagnosis and treatment of pneumonitis.

\section{Case Description}

A 51-year-old male was seen in August 2005 because of $\mathrm{HCV}$ infection. He had been using intravenous (i.v.) drugs until 1985 and his medical history revealed multiple total hip replacements and revisions because of hip necrosis attributed to i.v. drug-related blood-borne infections. Liver function tests were abnormal: alanine aminotransferase (ALAT) $237 \mathrm{IU} / \mathrm{L}$ (normal $<45 \mathrm{IU} / \mathrm{L}$ ), aspartate aminotransferase (ASAT) $235 \mathrm{IU} / \mathrm{L}$ (normal $<50 \mathrm{IU} / \mathrm{L}$ ), $\gamma$-glutamyl transpeptidase $241 \mathrm{IU} / \mathrm{L}$ (normal $<55 \mathrm{IU} / \mathrm{L}$ ), and bilirubin $19 \mu \mathrm{mol} / \mathrm{L}$ (normal $<10 \mu \mathrm{mol} / \mathrm{L}$ ). The patient was infected with genotype $3 \mathrm{HCV}$ virus with high viral load $\left(>5 \times 10^{5} \mathrm{IU} / \mathrm{ml}\right)$. A liver biopsy was performed and showed moderate necroinflammation with portoportal fibrosis (METAVIR; grade A2, score F2). In view of this advanced stage we offered the patient a 24-week treatment for $\mathrm{HCV}$ consisting of peginterferon $\alpha-2 b$ (Pegintron ${ }^{\circledR}$; $150 \mu \mathrm{g}$ s.c. weekly) in combination with ribavirin (Rebetol $^{\circledR} ; 400 \mathrm{mg}$ twice daily).

Four weeks after starting treatment he consulted us for a dry cough. Chest X-ray at that time showed no abnormalities. Although dry, nonproductive cough is usually caused by ribavirin, it typically clears after stopping the drug. The dry cough, however, persisted after end of treatment, being the reason to consult a chest physician. Physical examination revealed bibasal crepitations. A new chest radiograph showed bilaterally a diffuse, interstitial pattern (Fig. 1a) and chest high-resolution computed tomography (HRCT) demonstrated bilateral ground-glass opacities in central and upper zones (Fig. 1b). Pulmonary function tests indicated a restriction and a diminished diffusing capacity. Maximal incremental cycle ergometry showed decreased breathing reserve $(0 \mathrm{l} / \mathrm{min})$, high breathing frequency $(65 /$ $\mathrm{min}$ ), and exercise-induced hypoxemia caused by an oxygen uptake problem, compatible with interstitial pulmonary disease. Results from bronchoalveolar lavage supported a diagnosis of drug-induced interstitial pneumonitis (cell count $1.68 \times 10^{9} / \mathrm{L}, 73 \%$ lymphocytes, CD4/CD8 ratio $0.5)$. The results of cultures and stains of the bronchoalveolar lavage specimens were negative for bacteria, fungi, acid-fast bacteria, cytomegalovirus, herpes simplex virus, and malignant cells. There were no signs of infection (blood culture was negative).

As after 6 weeks the cough persisted, steroids up to $40 \mathrm{mg}$ daily were started, which resulted in slow amelioration of symptoms, normalization of pulmonary function tests, and disappearance of the ground-glass effect on HRCT. One year after end of treatment the patient is well, without evidence of recurrence of hepatitis $\mathrm{C}$.

\section{Methods}

\section{Literature}

First we performed a literature search for articles on pneumonitis as a side-effect of $\mathrm{HCV}$ treatment in order to obtain a comprehensive overview of this particular side-effect. We took advantage of the PubMed and Web of Science interface (http://www.ncbi.nlm.entrez and http://apps.isiknowledge. com) and searched with the following keywords: interferon, interstitial, pneumonitis, and hepatitis $\mathrm{C}$, for the period 1990-2008. Articles written in English, French or German were included in the analysis. Furthermore, we searched the three drug toxicity databases. We included the Netherlands Pharmacovigilance Center (www.lareb.nl) database and the
Fig. 1 a Chest X-ray with diffuse, bilateral interstitial pattern. b High-resolution computer tomography image showing bilateral ground-glass opacities in central zone
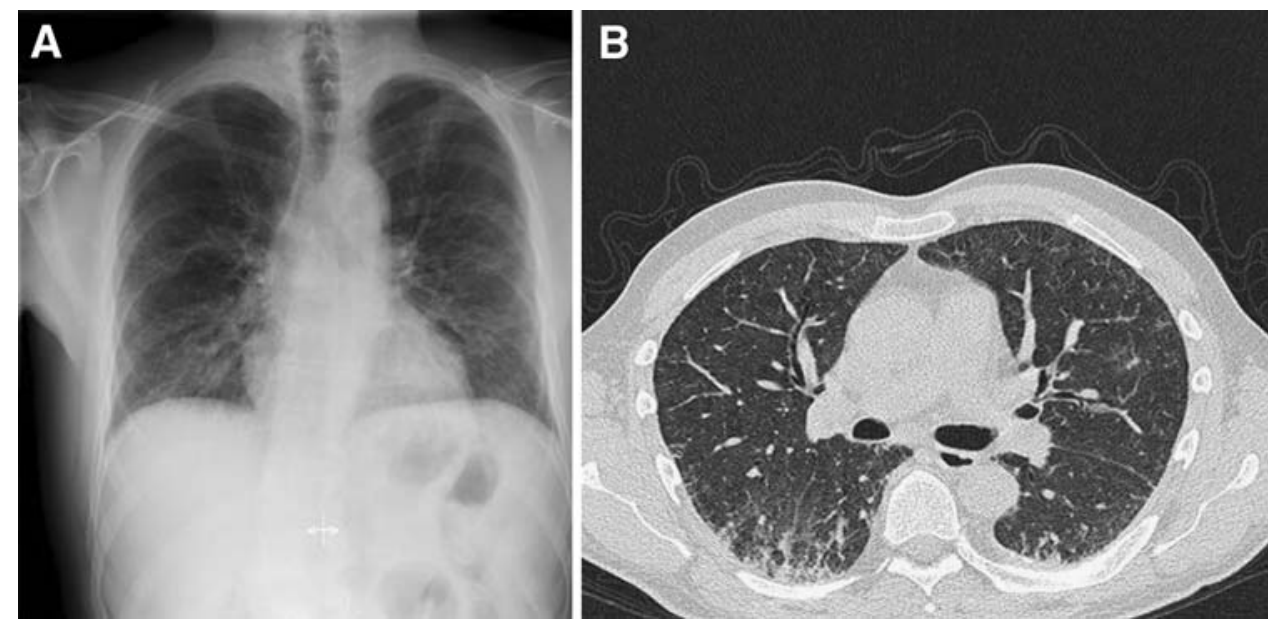
Drug-Induced Lung Diseases database (www.pneumotox. com), and lastly we performed an exhaustive search of the database of the World Health Organization (WHO) via the Uppsala monitoring center (http://www.who-umc.org). We used as keywords interferon and pneumonitis. The WHO database is a collection of data about adverse drug reactions from around the world, especially from countries that are members of the WHO, and the generation of signals of drugs which might possibly have problematic side-effects.

Inclusion criteria were cases that developed interstitial pneumonitis in the setting of HCV treatment, written in English, French or German. Exclusion criteria were other pulmonary diseases, e.g., sarcoidosis, exacerbation of asthma, BOOP, acute respiratory distress syndrome (ARDS), infectious pneumonia, liver transplanted patients, HIV co-infected patients, and interferon beta treatment. Patients who developed interstitial pneumonitis during interferon therapy with a disease other then hepatitis C were also excluded. The references of the traced articles were scrutinized for additional articles.

Initial analysis yielded a total of 291 articles. The abstracts of this set of articles were scrutinized for cases that developed (interstitial) pneumonitis in the setting of HCV treatment. Subsequently data were retrieved with special attention to the following items: demographics (ethnicity, gender, and age), dosage and type of (peg)interferon, concomitant use of ribavirin (dosage), symptoms, interstitial pneumonitis, onset, symptoms, and outcome on follow-up.

\section{Results}

\section{Articles}

We retrieved 19 articles, which contained detailed clinical descriptions of 25 cases of interstitial pneumonitis during or after HCV treatment. Our own case was added to the analysis. Articles were published in the time frame 19882008.

\section{Demographics and Treatment}

A total of 25 cases, 12 (48\%) males and 13 (52\%) females, with mean age of 55.2 years, developed an interstitial pneumonitis. Ethnicity was mentioned in seven cases, being Caucasian (five) and Asian (two). Tables 1 and 2 present the demographic characteristics of all cases.

Fourteen patients were treated with conventional interferon, while 11 patients developed pneumonitis during or after treatment with peginterferon and ribavirin.
Interferon Therapy Cases

Interferon $\alpha-2 b$ had been used in eight patients (62\%), while interferon $\alpha-2 \mathrm{a}$ and lymphoblastoid interferon (6 MU q.d. $\times 10$ days, then 6 MU t.i.w.) was used in one single case. Interferon type was not specified in three cases. Dosages regimes varied with type of interferon and are presented in Table 2. Onset of symptoms of interstitial pneumonitis ranged from 20 days to 23 weeks of therapy. Symptoms included cough, dyspnea, and fever.

\section{Combination Therapy Cases}

Peginterferon $\alpha$-2b was used in eight patients (67\%), while peginterferon $\alpha-2 \mathrm{a}$ was used in four patients (33\%). Consensus interferon (Infergen, $9 \mu$ g q.d.) was given in a single case. Dosage regimes varied from 100 to $180 \mu \mathrm{g} / \mathrm{week}$, depending on type of peginterferon, and from 400 to $1,200 \mathrm{mg} /$ day for ribavirin. In two cases Amantadine was added to the treatment regimen.

Onset of symptoms of interstitial pneumonitis ranged from 2 to 12 weeks of therapy.

\section{Therapy for Interstitial Pneumonitis}

In all interferon cases therapy was discontinued, and five of these cases resolved without treatment [8-10]. Eight patients needed to be treated with various steroids. Interstitial pneumonitis in a 72-year-old female patient was treated with $30 \mathrm{mg} / \mathrm{day}$ prednisolone, and she was then maintained on a regimen of intermittent pulse therapy with $100 \mathrm{mg} /$ day; a 56 -year-old male patient was started with $2 \mathrm{~g} /$ day methylprednisolone for 3 days and $40 \mathrm{mg} /$ day prednisolone for 2 days [10]. Prednisolone $(60 \mathrm{mg} /$ day $)$ and $100 \mathrm{mg} /$ day azathioprine were given after a relapse of interstitial pneumonitis that was initially treated with $30 \mathrm{mg} /$ day prednisolone [11].

In one case of therapy with methylprednisolone pulse therapy, $1 \mathrm{~g} /$ day i.v. for 3 days was given, followed by $40 \mathrm{mg} /$ day oral prednisolone twice over 2 weeks; the other cases in that article received $50 \mathrm{mg} /$ day oral prednisone [12]. Therapy for one case was not specified [13].

In eight cases combination therapy was discontinued and steroid therapy was initiated. While dosage and length of steroid treatment was highly variable, most authors started at a relatively high dosage. Intravenous therapy with $180 \mathrm{mg} /$ day methylprednisolone was started in one case [14], while other authors started with $125 \mathrm{mg} /$ day prednisolone $[15,16]$. Others started patients on oral steroid therapy $(40 \mathrm{mg}$ ) $[6,17$, this study], while two authors initiated inhalation steroids $[18,19]$.

Interstitial lung disease resolved in one case with oral antibiotics, given under presumptive diagnosis of 


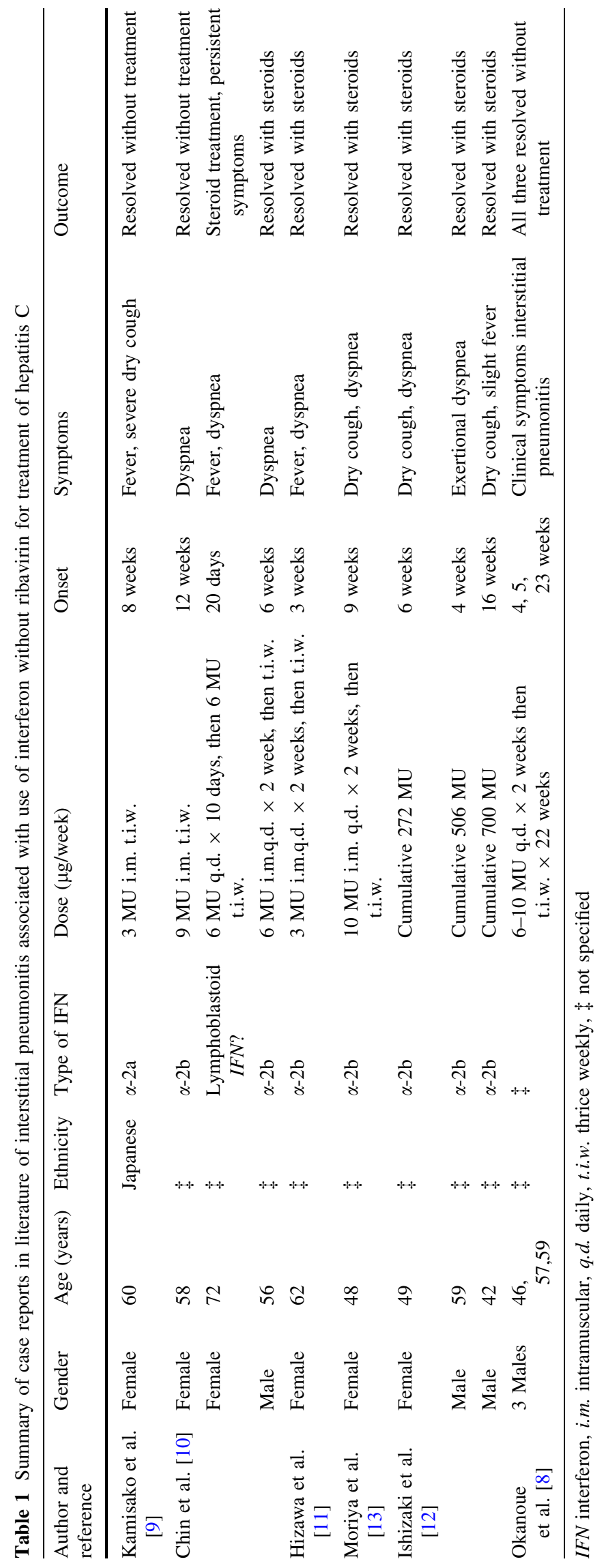


Table 2 Summary of case reports in literature of interstitial pneumonitis associated with use of pegylated interferon with ribavirin for treatment of hepatitis $\mathrm{C}$

\begin{tabular}{|c|c|c|c|c|c|c|c|c|c|}
\hline $\begin{array}{l}\text { Author and } \\
\text { reference }\end{array}$ & Gender & $\begin{array}{l}\text { Age } \\
\text { (years) }\end{array}$ & Ethnicity & $\begin{array}{l}\text { Type of } \\
\text { (peg)IFN }\end{array}$ & $\begin{array}{l}\text { Dose }(\mu \mathrm{g} / \\
\text { week) }\end{array}$ & $\begin{array}{l}\text { Ribavirin } \\
(\mathrm{mg})\end{array}$ & $\begin{array}{l}\text { Onset } \\
\text { (week) }\end{array}$ & Symptoms & Outcome \\
\hline $\begin{array}{l}\text { Fuhrmann } \\
\text { et al. [15] }\end{array}$ & Male & 51 & Asian & $\alpha-2 b$ & 100 & 1,200 & 5 & $\begin{array}{l}\text { Fever, dry } \\
\text { cough, } \\
\text { dyspnea }\end{array}$ & Death \\
\hline $\begin{array}{l}\text { Abi-Nassif } \\
\text { et al. [14] }\end{array}$ & Male & 49 & Caucasian & $\alpha-2 b$ & 150 & 1,200 & 2 & $\begin{array}{r}\text { Cough and } \\
\text { dyspnea }\end{array}$ & Death \\
\hline $\begin{array}{l}\text { Carrillo-Esper } \\
\text { et al. [16] }\end{array}$ & Female & 43 & $\ddagger$ & $\alpha-2 b$ & 120 & 800 & 48 & $\begin{array}{l}\text { Dyspnea, } \\
\text { cough, fever }\end{array}$ & Death \\
\hline $\begin{array}{l}\text { Hillier et al. } \\
\text { [17] }\end{array}$ & Female & 68 & Caucasian & $\begin{array}{l}\text { Consensus } \\
\text { IFN }\end{array}$ & $9 \mu \mathrm{g}$ daily & 1,000 & 8 & $\begin{array}{l}\text { Shortness of } \\
\text { breath }\end{array}$ & Discontinued and steroids \\
\hline \multirow{2}{*}{$\begin{array}{l}\text { Renou et al. } \\
\text { [18] }\end{array}$} & \multirow[t]{2}{*}{ Female } & \multirow[t]{2}{*}{58} & \multirow[t]{2}{*}{ Caucasian } & $\alpha-2 b$ & 150 & 1,000 & 12 & Dyspnea & \multirow{2}{*}{$\begin{array}{l}\text { Discontinued and resolved } \\
\text { with inhalation steroids }\end{array}$} \\
\hline & & & & $\alpha-2 a$ & 180 & $1,000+\mathrm{A}^{*}$ & 12 & dyspnea & \\
\hline $\begin{array}{l}\text { Kumar et al. } \\
\text { [6] }\end{array}$ & Female & 48 & Hispanic & $\alpha-2 a$ & 180 & $\ddagger+A^{*}$ & 6 & Fever, cough & $\begin{array}{l}\text { Discontinued and resolved } \\
\text { with steroids }\end{array}$ \\
\hline $\begin{array}{l}\text { Midturi et al. } \\
\text { [7] }\end{array}$ & Female & 71 & $\ddagger$ & $\alpha-2 a$ & 180 & 800 & 6 & $\begin{array}{l}\text { Cough, } \\
\text { diarrhea, } \\
\text { nausea }\end{array}$ & Resolved after discontinuation \\
\hline $\begin{array}{l}\text { Chen et al. } \\
\text { [20] }\end{array}$ & Female & 47 & $\ddagger$ & $\alpha-2 b$ & $\ddagger$ & $\ddagger$ & + & Dry cough & $\ddagger$ \\
\hline Son et al. [21] & Male & 50 & $\ddagger$ & $\alpha-2 a$ & 180 & 1,000 & 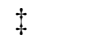 & $\ddagger$ & Resolved after discontinuation \\
\hline $\begin{array}{l}\text { Rocca et al. } \\
\text { [22] }\end{array}$ & Male & 63 & $\ddagger$ & $\alpha-2 b$ & $\ddagger$ & 400 & 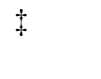 & $\begin{array}{l}\text { Signs of } \\
\text { pneumonia }\end{array}$ & $\ddagger$ \\
\hline $\begin{array}{l}\text { Slavenburg } \\
\text { et al. } \\
\text { [this study] }\end{array}$ & Male & 51 & Caucasian & $\alpha-2 b$ & 150 & 800 & 4 & Dry cough & $\begin{array}{l}\text { End of treatment and resolved } \\
\text { with steroids }\end{array}$ \\
\hline $\begin{array}{l}\text { Nemivant } \\
\text { et al. [23] }\end{array}$ & Male & 72 & $\ddagger$ & $\alpha-2 b$ & 150 & 800 & 16 & $\begin{array}{l}\text { Dyspnea, } \\
\text { hypoxia }\end{array}$ & $\begin{array}{l}\text { Discontinuation and resolved } \\
\text { with steroids }\end{array}$ \\
\hline $\begin{array}{l}\text { Rothfuss et al. } \\
\text { [19] }\end{array}$ & Female & 62 & $\ddagger$ & $\alpha-2 b$ & $\begin{array}{l}\text { 4.5 MU } \\
\text { i.m. } \\
\text { t.i.w. }\end{array}$ & 1,000 & 9 & $\begin{array}{l}\text { Dry cough and } \\
\text { dyspnea }\end{array}$ & Inhalation steroids \\
\hline
\end{tabular}

$P E G$-IFN pegylated interferon, A* Amantadine, $\ddagger$ not specified

community-acquired pneumonia. She recovered without sequel [7]. In four combination-therapy cases the dosage of steroid therapy was not defined [20-23].

\section{Pneumonitis Cases from Drug Toxicity Databases}

We identified 60 pneumonitis cases in association with (peg)interferon $\alpha$ from the WHO database. In 33 cases the indication of (peg)interferon (and ribavirin) combination treatment was HCV. There were 16 (48\%) males and 15 (45\%) females in this cohort, with mean age of 53 years. We failed to retrieve cases that met the inclusion criteria from the Netherlands Pharmacovigilance Center and DrugInduced Lung Diseases databases.

Interferon monotherapy was used in three $(9 \%)$ patients. Interferon $\alpha-2 b$ in combination with ribavirin was used in eight patients (24\%), while interferon $\alpha-2 \mathrm{a}$ in combination with ribavirin was used in a single case.

Peginterferon $\alpha-2 b$ in combination with ribavirin had been used in 6 patients $(18 \%)$, while in 13 patients $(39 \%)$ combination therapy with peginterferon $\alpha$-2a was used. In two cases type of interferon and ribavirin was not described.

Dosages regimes varied from 80 to $180 \mu \mathrm{g} / \mathrm{week}$, depending on type of peginterferon, in combination with ribavirin (800-1,200 $\mathrm{mg} / \mathrm{day})$. Onset of symptoms of interstitial pneumonitis ranged from 23 days to 10 months of therapy. Four patients recovered and one patient died after drug-induced pneumonitis; outcomes of the remaining patients were not described. There was no description on treatment regimen for pneumonitis.

\section{Mortality}

Collectively, the cohort consisted of 25 patients from literature cohort and 33 patients from the drug toxicity database. Four patients $(7 \%)$ from these two cohorts died following development of interstitial pneumonitis. All patients had been treated with peginterferon $\alpha-2 b$.

Death in one case was due to multiple organ failure [14], in another case due to cerebral edema [15], and in one case 
because of development of acute cholestatic hepatitis [16]. The cause of death of one case from the WHO database was not described.

\section{Discussion}

Interstitial pneumonitis occurs only rarely as a side-effect of HCV combination treatment and often leads to discontinuation of therapy, which has great implications for patients. In this article we presented our case of pneumonitis during combination therapy and performed a review in order to generate guidelines to manage symptoms and treatment. Given the paucity of reports with interstitial pneumonitis after ribavirin monotherapy, we suspect that interferon is the culprit.

The most common presenting symptom of pneumonitis is any combination of dry cough, dyspnea, fever, and fine inspiratory crackles noted on examination. Hemoptysis, wheezing, and signs of consolidation are rare. Onset of pneumonitis can be at any stage of $\mathrm{HCV}$ treatment, supporting the idiosyncratic nature of this side-effect.

Chest radiographs usually show bilateral patchy infiltrates or opacifications, and thin-section CT scans show bilateral patchy consolidation as well as ground-glass attenuation [24].

In most cases, symptoms of pneumonitis are reversible after cessation of treatment with (peg)interferon and ribavirin, again in support of drug-induced interstitial pneumonitis.

There is no consensus regarding treatment of interstitial pneumonitis induced by (peg)interferon and ribavirin. Upon review of the literature, three options are possible: first, to stop combination treatment of $\mathrm{HCV}$ and wait until the disease resolves, which was done in a limited number of cases [7-10]; second, to give steroids, although dosage and route of administration regimes vary widely [6, 10-18, this study]; and thirdly, in therapy-resistant or relapsing cases, adding azathioprine to steroids may be beneficial in order to resolve the interstitial pneumonitis [11].

The relatively high mortality rate in our series suggests that a more aggressive approach is warranted, and favors the early administration of steroids.

One remarkable finding is that mortality occurred exclusively in patients with peginterferon-induced pneumonitis in comparison with conventional interferon (7\% versus $0 \%$ ). The reason for this is unclear, but (peg)interferon has been associated with other pulmonary toxicity such as sarcoidosis, pleuritis, BOOP, and exacerbation of asthma.

Patients who died in the combination-therapy group were relatively young and had no relevant pulmonary or other severe diseases in their medical history. The doses of peginterferon and ribavirin varied but ranged within limits offered by treatment guidelines [25].
The mortality, only observed in patients treated with peginterferon and ribavirin combination therapy, raises the issue of whether the peg molecule increases the severity of pneumonitis once it arises. Interferon toxicity is generally dose and duration dependent [26], which leads us to speculate that pulmonary toxicity may occur more severely with long-acting peginterferon; however, we saw no effect of dosage on the occurrence of pneumonitis. Patients died due to different causes (e.g., hypoxia-induced cerebral edema, acute cholestatic hepatitis, and multi-organ failure), all were induced by complications after initially interstitial pneumonitis. One alternative explanation for the increased mortality might be that all patients with peginterferon were also treated with ribavirin, although ribavirin per se is not associated with pulmonary toxicity.

Our data suggest no significant difference between interferon $\alpha-2 \mathrm{a}$ or $2 \mathrm{~b}$, which suggest it is not due to the interferon molecule. In most interferon monotherapy cases of interstitial pneumonitis in HCV treatment in Japan the use of Sho-Saiko-to, a herbal medicine, led to pneumonitis. Sho-Saiko-to has been approved by the Japanese Ministry of Health and Welfare and has often been administered in chronic viral liver disease [27].

The mechanism of this side-effect, probably caused by interferon, remains unclear and several pathophysiological mechanisms have been proposed, centering on the known immunomodulatory activity of interferon [28]. Interferon has direct antiviral and immunomodulatory effect, including cytokine reduction, increased natural killer cell function, and enhanced cellular expression of major histocompatibility class 1 antigens [28-30]. It is plausible that interferon triggers a lung-specific immune-mediated response resulting in interstitial pneumonitis, similar to other autoimmune diseases.

\section{Conclusion}

Failure to recognize interferon-associated pulmonary toxicity may result in persistence of pulmonary damage. Mortality was seen only in patients treated with pegylated interferon combination therapy. Therefore, clinicians should be aware of development of interstitial pneumonitis in chronic hepatitis $\mathrm{C}$ patients who develop pulmonary symptoms such as cough or dyspnea. The threshold for obtaining chest X-ray or pulmonary HRCT scan in these patients should be low.

Acknowledgments The authors are indebted to the national pharmacovigilance centers that contributed data for this study. The opinions and conclusions, however, are not necessarily those of the various centers, nor of the WHO. 
Open Access This article is distributed under the terms of the Creative Commons Attribution Noncommercial License which permits any noncommercial use, distribution, and reproduction in any medium, provided the original author(s) and source are credited.

\section{References}

1. Hoofnagle JH, Seeff L. Peginterferon and ribavirin for chronic hepatitis C. N Engl J Med. 2006;355:2444-2451. doi:10.1056/ NEJMct061675.

2. Lauer GM, Walker BD. Hepatitis $\mathrm{C}$ virus infection. $N$ Engl $J$ Med. 2001;345:41-52. doi:10.1056/NEJM200107053450107.

3. Janssen HL, Berk L, Vermeulen M, Schalm SW. Seizures associated with low-dose alpha-interferon. Lancet. 1990;336:1580. doi:10.1016/0140-6736(90)93356-T.

4. Fried MW. Side effects of therapy of hepatitis $C$ and their management. Hepatology. 2002;36:S237-S244. doi:10.1002/ hep. 1840360730 .

5. Fattovich G, Giustina G, Favarato S. Ruol A. A survey of adverse events in 11, 241 patients with chronic viral hepatitis treated with alfa interferon. J Hepatol. 1996;24:38-47. doi:10.1016/S01688278(96)80184-X.

6. ShivaKumar K, Russo MW, Borczuk AC, et al. Significant pulmonary toxicity associated with interferon and ribavirin therapy for hepatitis C. Am J Gastroenterol. 2002;97:2432-2440. doi: 10.1111/j.1572-0241.2002.05999.x.

7. Midturi J, Sierra-Hoffman M, Hurley D, Winn R, Beissner R, Carpenter J. Spectrum of pulmonary Toxicity associated with use of interferon therapy for hepatitis C. Case report and review of literature. Clin Infect Dis. 2004;39:1724-1729. doi:10.1086/ 425746.

8. Okanoue T, Sakamoto S, Itoh Y, et al. Side effects of high-dose interferon therapy for chronic hepatitis C. J Hepatol. 1996;25:283-291. doi:10.1016/S0168-8278(96)80113-9.

9. Kamisako T, Adachi Y, Chihara J, Yamamoto T. Interstitial pneumonitis and interferon-alfa. BMJ. 1993;306:896.

10. Chin K, Tabata C, Sataka N, Nagai S, Moriyasu F, Kuno K. Pneumonitis associated with natural and recombinant interferon alfa therapy for chronic hepatitis C. Chest. 1994;105:939-941. doi:10.1378/chest.105.3.939.

11. Hizawa N, Kojima J, Kojima T, et al. A patient with chronic hepatitis $\mathrm{C}$ who simultaneously developed interstitial pneumonia, hemolytic anemia and cholestatic liver dysfunction after alphainterferon administration. Intern Med. 1994;33:337-341. doi: 10.2169/internalmedicine.33.337.

12. Ishizaki T, Sasaki F, Ameshima S, et al. Pneumonitis during interferon and/or herbal drug therapy in patients with chronic active hepatitis. Eur Respir J. 1996;9:2691-2696. doi:10.1183/ 09031936.96.09122691.

13. Moriya K, Yasuda K, Koike K, et al. Induction of interstitial pneumonitis during interferon treatment for chronic hepatitis $\mathrm{C}$. J Gastroenterol. 1994;29:514-517. doi:10.1007/BF02361253.

14. Abi-Nassif S, Mark EJ, Fogel RB, Hallisey RK Jr. Pegylated interferon and ribavirin-induced interstitial pneumonitis with ARDS. Chest. 2003;124:406-410. doi:10.1378/chest.124.1.406.
15. Fuhrmann V, Kramer L, Bauer E, et al. Severe interstitial pneumonitis secondary to pegylated interferon alpha-2b and ribavirin treatment of hepatitis C infection. Dig Dis Sci. 2004;49:1966-1970. doi:10.1007/s10620-004-9602-3.

16. Carrillo-Esper R, González-Avila D, Uribe-Ríos M, MéndezSánchez N. Interstitial pneumonitis associated with pegylated interferon alpha-2b therapy for chronic hepatitis C. Case report. Ann Hepatol. 2008;7:87-90.

17. Hillier AE, Mand J, Raza A, Markov M, Nadir A. Consensus interferon induced interstitial pneumonitis in a patient with HCV. Am J Gastroenterol. 2006;101:200-202. doi:10.1111/j.15720241.2005.50006_9.x.

18. Renou C, Germain S, Harafa A, et al. Pneumonia recurrence during chronic hepatitis C treatment. Am J Gastroenterol. 2005;100:1625-1626. doi:10.1111/j.1572-0241.2005.50006_9.x.

19. Rothfuss KS, Bode JC. Interstitial pneumonitis during combination therapy with interferon- $\alpha$ and ribavirin in a patient with chronic hepatitis C. Z Gastroenterol. 2002;40:807-810. doi: 10.1055/s-2002-33879.

20. Chen YC, Lu SN, Lin MC. Interstitial pneumonitis after combination therapy with pegylated interferon alpha-2b and ribavirin for chronic hepatitis C. Chang Gung Med J. 2007;30:92-97.

21. Son BK, Sohn JH, Kim TY, Park YK, Jeon YC, Han DS. Pulmonary toxicity by pegylated interferon alpha-2a in a patient with chronic hepatitis C. Korean J Hepatol. 2007;13:103-107.

22. Rocca $P$, Dumortier $J$, Tanière $P$, et al. Induced interstitial pneumonitis: role of pegylated interferon alpha $2 \mathrm{~b}$. Gastroenterol Clin Biol. 2002;26:405-408.

23. Nemivant RR, Hammadeh R, Shah N, Villanueva J. Interstitial pneumonitis due to pegylated interferon alfa- $2 \mathrm{~b}$ and ribavirin. Chest. 2003;124:242S. doi:10.1378/chest.124.1.242.

24. Park JS, Lee KS, Kim JS, et al. Nonspecific interstitial pneumonia with fibrosis: radiographic and CT findings in seven patients. Radiology. 1995;195:645-648.

25. Strader DB, Wright T, Thomas DL. Diagnosis, management, and treatment of hepatitis C. Hepatology. 2004;39:1147-1171. doi: 10.1002/hep.20119.

26. Tahan V, Ozseker F, Guneylioglu D, et al. Sarcoidosis after use of interferon for chronic hepatitis C: report of a case and review of the literature. Dig Dis Sci. 2003;48:169-173. doi:10.1023/ A: 1021759120428.

27. Japanese Welfare Ministry. Report on drug side effect. No. 125, 1994.

28. Abbas AK, Lichtman AH, Pober JS. Effector mechanisms of immune responses. In: Cellular and molecular immunology. 3rd ed. Philadelphia: WB Saunders; 1997:245-338.

29. Borden EC, Parkinson D. A perspective on the clinical effectiveness and tolerance of interferon alpha. Semin Oncol. 1998; 25:3-8.

30. Tilg H. New insights into the mechanisms of interferon alfa: an immunoregulatory and anti-inflammatory cytokine. Gastroenterology. 1997;112:1017-1021. doi:10.1053/gast.1997.v112.pm 9041265 . 